\title{
CARTAS DE AMOR A STALIN
}

\author{
Juan Mayorga
}

\section{NOTA PREVIA DEL AUTOR}

Cartas de amor a Stalin es una historia de amor en la que intervienen tres personajes: un hombre, una mujer y el diablo.

Es una meditación sobre la necesidad que tiene el artista de ser amado por el poder, necesidad tan fuerte como la que el poder tiene de ser amado por el artista.

Es una fantasía basada en la terrible experiencia de Mijaíl Bulgákov, enorme escritor al que el stalinismo condenó al silencio. La acción transcurre en los años treinta, cuando, desesperado por la censura absoluta que cae sobre su obra, Bulgákov se convierte en «escritor para un sólo lector»: escribe carta tras carta a Stalin reclamando o su libertad como artista en la URSS, o su libertad para salir del país. Marginado de una sociedad ante la que se le presenta como traidor, sólo sostenido por el aliento de su esposa, Bulgákov espera en vano una respuesta del gran camarada.

Hasta que un día recibe una llamada telefónica de alguien que se identifica como Stalin. Bulgákov no tiene ninguna duda al respecto: es 
Stalin quien le llama, quien se dirige a él respetuosamente, quien elogia su obra. Por desgracia, la llamada se corta cuando el dictador está a punto de proponer a Bulgákov un encuentro cara a cara.

Aquella llamada interrumpida es la pequeña base sobre la que Bulgákov levanta una gran esperanza. Tanto como desea ser libre, el artista desea volver a oír la voz del tirano. Ambos deseos le llevan a escribir compulsivamente, a la búsqueda de la carta magistral capaz de conquistar a Stalin. Su deseo de encontrarse con él le arrastra muy lejos del mundo real, al que su esposa quiere mantenerlo unido. Por fin, en su enajenación Bulgákov realiza su deseo: un Stalin fantasmagórico le visita. Pero la mujer no cederá al fantasma su lugar, sin lucha.

JUAN MAYORGA

NOTA DEL DIRECTOR DE ESCENA

Cartas de amor a Stalin es una obra que trasciende el referente histórico para plantearnos una analogía sobre las relaciones entre el poder del Estado a través de una figura emblemática como fue Stalin y uno de los múltiples intelectuales, novelista y autor teatral, Bulgákov, que vio cómo sus obras iban siendo arrinconadas ante la marea de la asepsia crítica manejada por el aparato stalinista a través de ese extraño instrumento llamado «realismo-socialista».

A partir de un hecho real, el escritor penetra en un proceso paranoico que le conducirá a una práctica de autodestrucción, no sólo de su creación literaria sino también de su entorno familiar. Las ficciones del escritor irán creando una imagen en la que el monstruoso dictador se convertirá en un inquietante compañero de fatigas hacia un horizonte sin futuro. Tal vez los intelectuales se muevan, a veces, en el delicado equilibrio entre la sacralización o la demonización cuando sus relaciones con la realidad se deforman por efecto de una mirada aislada de los problemas cotidianos. Desde luego, el stalinismo, como cualquier tipo de régimen dictatorial, no fue un juego de niños y, por ello, muchos de los más grandes hombres de la cultura nacida de la revolución de octubre fueron eliminados no sólo de las fotografías, sino también de la vida cotidiana por medios tan soeces como el fusilamiento o la inducción al suicidio. Bajo estas condiciones de falta de libertad ¿se puede 
escribir dando rienda suelta a un mundo propio alejado de los fantasmas de la autocensura o de la tortura cierta de la censura? Dilemas que quizás convenga recordar en tiempos de democracia, por muy burguesa que sea, pues no hace tanto en nuestro país ocurrieron casos que muy bien pudieran parecerse al de Bulgákov. Dejar a un lado la memoria histórica es jugar con fuego y si no que se lo pregunten a los espíritus de esa vieja Europa que con tanta frecuencia abren la caja de Pandora para sacar a pasear sus carencias y sus vergüenzas.

GUILLERMo Heras

\section{CARTAS DE AMOR A STALIN}

En casa de los Bulgákov. Allí donde él escribe.

(Bulgákov escribe. Hasta que nota que su mujer lo está mirando. Ella acaricia la mano con la que él escribe.)

Bulgákova.- ¿Sabes cuánto he deseado este momento? Llevabas meses sin hacerlo. Ni una palabra desde Corazón de perro. ¿Qué es? ¿Una comedia?

\section{(Bulgákov niega.)}

Bulgákova._-¿Una novela? ¿La segunda parte de La guardia blanca? (Bulgákov niega.)

BulgákOVA.—¿Un poema?

BulgáKov.-Una carta.

BulgáKovA.—(Decepcionada.) ¿Una carta?

Bulgákov.-¿Quieres que te la lea?

Bulgákova.-Sabes que me gusta ser la primera en conocer tus obras.

Una carta es otra cosa, desde luego. Al verte con la pluma sobre el 
papel, pensé que... Pero has vuelto a sentarte aquí, eso es lo que importa. Lo importante es que has vuelto al lugar en que escribiste El apartamento de Zoika. Claro que sí, léeme esa carta.

BulgÁKov.-(Leyendo.) «Estimado camarada: Mi obra La huida, cuyo estreno estaba previsto para el próximo septiembre, ha sido prohibida durante los ensayos. Las representaciones de La isla púrpura han sido prohibidas. Los días de los Turbín, después de trescientas representaciones, ha sido prohibida. El apartamento de Zoika, después de doscientas representaciones, ha sido prohibida. Así pues, mis cuatro obras teatrales se encuentran prohibidas. La edición de mis relatos ha sido prohibida, igual que han sido prohibidos mis ensayos satíricos. La lectura pública de Las aventuras de Chichikov ha sido prohibida. La publicación de mi novela La guardia blanca en la revista Rossia ha sido prohibida. No tengo ánimos para vivir en un país en el que no puedo ni representar ni publicar mis obras. Me dirijo a usted para pedirle que se me devuelva mi libertad como escritor (Pausa.) o se me expulse de la Unión Sovietica junto con mi esposa».

\section{(Pausa.)}

Bulgákova._¿Irnos de Rusia, Mijail?

(Largo silencio. Bulgákov no replica.)

BUlgáKova.- ¿De verdad crees que podemos vivir en otro país? No creo que podamos. Es nuestro cielo, nuestra lengua, nuestra gente...

(Largo silencio. Bulgákov no replica.)

Bulgákova.- Ya, ya sé que todos parecen haber cambiado, que éste ya no es el país en que nacimos, pero aquí, en esta casa... Ocurra lo que ocurra ahí fuera, nosotros, tú y yo, podemos ser felices aquí, juntos.

(Largo silencio. Bulgákov no replica.)

Bulgákova.-Lo importante es que estemos juntos. Donde sea, Mijail, donde tú quieras, con tal de que estemos juntos.

(Lo toca con amor. Él besa las manos de ella.)

BulgáKov.—«Firmado: Mijail Bulgákov. Moscú, julio de 1929».

(Pausa.)

BulgáKova.- ¿A quién la diriges?

BULGÁKOV.-A Stalin.

(Pausa.) 
(Bulgákov lee una carta a su mujer. Con poca pericia, ella le remienda una camisa.)

BULGÁKov.— «Estimado camarada: Durante los últimos años, he contabilizado trescientos un artículos aparecidos sobre mí en la prensa soviética. Tres eran laudatorios; doscientos noventa y ocho, injuriosos. «Bulgákov es un perro que rebusca en la basura», así me ha caracterizado el número ocho de Izvestia. En el número catorce del Komsomolskaia se me llama «burgués que lanza escupitajos empozoñados pero impotentes sobre la clase trabajadora». Todas mis obras han recibido comentarios corrosivos por parte del diario Pravda. Incluso en la Enciclopedia Soviética he sido insultado. (Pausa.) Toda la prensa soviética, y junto a ella todas las instituciones encargadas del control del teatro, se esfuerzan en demostrar que un escritor como Mijail Bulgákov no puede vivir en la Unión Soviética. Probablemente, tienen toda la razón». (Interrumpe la lectura, irritado.) ¿Puedes dejar eso? ¿Puedes tomarte esto en serio?

(La mujer deja lo que está haciendo.)

Bulgákova.-Te estoy escuchando. Te he escuchado todo el tiempo.

Bulgákov.-Necesito más. Lo que yo necesito... ¿Por qué Stalin no responde a mis cartas? ¿Puedes decírmelo? ¿Qué es lo que estoy haciendo mal?

\section{(Silencio.)}

Bulgákova.-Tú eres el escritor. Conoces el efecto de las palabras sobre la gente. ¿Cómo reaccionará Stalin ante una frase como ésta? (Lee.) «Toda la prensa soviética, y junto a ella todas las instituciones encargadas del control del teatro, se esfuerzan en demostrar que un escritor como Mijail Bulgákov no puede vivir en la Unión Soviética.» ¿Cómo reaccionará Stalin ante esas palabras?

(Bulgákov no lo sabe. Silencio.)

Bulgákova.-Ojalá yo pudiera ayudarte... No conozco a Stalin. Lo más cerca que he estado de él ha sido en el estreno de Los días de los Turbín. Me dio la mano. Lo único que recuerdo de él son sus manos. El modo en que movía las manos.

(Intenta imitar el modo en que Stalin movía las manos. Pausa.) 
Bulgákova.-Si eso te ayuda, puedo... Imaginar que soy Stalin y reaccionar como él reaccionaría ante tu carta. Puedo ponerme en su lugar.

BulgákOV.—¿Ponerte tú en su lugar? ¿Tú en el lugar del hombre que ha prohibido mis obras?

BULGákova.-Si eso te ayuda...

BulgáKov.-Casi ha vuelto loco a nuestro amigo Zamiatin. Ha fusilado a Pilniak. Ha logrado que Maiakowski se suicide.

BULGÁKOVA.—Quiero ayudarte.

BULGÁkov.—¿Ponerte en la piel de ese hombre al que odio? Al que odias.

Bulgákova. - Con todas mis fuerzas, así lo odio. Pero incluso los hombres más odiosos creen tener razones para hacer lo que hacen. Y tú, Mijail, necesitas encontrar esas razones. Necesitas encontrar sus razones para volverlas contra él.

(Bulgákov vacila.)

BULGákov.-No funcionará. Sólo sabes cómo mueve las manos. ¿Qué sabes sobre su alma?

Bulgákova.-Usa tu imaginación. Imagina que soy Stalin.

BULGÁkov.—Eres la mujer que amo. ¿Cómo voy a imaginar...?

(Pero ella ya está buscando en su cuerpo el de Stalin. Sin convicción, Bulgákov acepta.)

Bulgákov.-Está bien, juguemos un rato. Supongamos que eres Stalin.

(Bulgákov escribe. Ella intenta representar ante él las reacciones de Stalin.)

Bulgákov.-Acabo de recibir un oficio del Comité Central del Teatro. Me comunican que se deniega el permiso de representación a mi última obra, La isla púrpura. En un par de renglones queda sepultado mi trabajo de años. No puedo escribir una palabra más sin preguntarme: Cuanto vaya a escribir en el futuro, ¿está condenado de antemano?

(Silencio. Escéptico, Bulgákov espera la reacción de su mujer. Ella vacila; busca postura, tono.) 
BulgákovA.—Camarada Bulgákov...

(Bulgákov niega, parodia la postura, el tono de su mujer: «Camarada Bulgákov...». La dirige hacia otra postura, otro tono: «Camarada Bulgákov...». Ella vuelve a intentarlo.)

Bulgákova.-Camarada Bulgákov... ¿Es usted consciente de...? (Se arrepiente; busca otra postura, otro tono.) Con La isla púrpura ha ido demasiado lejos. Ni siquiera su amigo Zamiatin se había atrevido a tanto.

BULGÁkov.-Stalin jamás diría eso. «Ni siquiera su amigo Zamiatin se había atrevido a tanto». Stalin jamás me compararía con el pobre Zami...

Bulgákova.-(Interrumpiéndole.) El Comité Central del Teatro ha calificado La isla púrpura como un libelo contra la Revolución.

\section{(Pausa. Bulgákov escribe.)}

BULGÁKOV.-No escribí La isla púrpura contra la Revolución, sino precisamente contra el Comité Central del Teatro... El Comité no es la Revolución, sino el asesino del espíritu creador. Su objetivo es... su objetivo es formar artistas atemorizados y serviles... Por eso dispara contra mí. Porque para Mijail Bulgákov la lucha contra la censura constituye el mayor deber de un artista. Un artista al que la libertad no es necesaria viene a ser como un pez al que el agua no es imprescindible.

BULGÁKOVA.- ¿Pretende impresionarme con metáforas tan anticuadas? ¿Cree que va a conmoverme con la apolillada retórica de un Gógol? Bulgákov, yo soy un hombre práctico. Vayamos al grano. Son sus propios colegas, escritores patriotas, quienes han denunciado su obra como un crimen contra la patria. Han sabido descubrir que sus sátiras ridiculizan a la Revolución.

BULGákov.-En la Unión Soviética, toda verdadera sátira es perseguida como un delito... (Se arrepiente; tacha.) ... como un crimen. Por verdadera sátira entiendo aquella que penetra en zonas prohibidas. En la Unión Soviética, la sátira es perseguida como un acto terrorista.

BULGákova.-No se haga el inocente. Usted ha publicado en el extranjero obras que hacen burla de nuestro pueblo.

Bulgákov.-En Praga, una revista de exiliados editó La guardia blanca cambiando el final... Han publicado bajo mi nombre palabras que yo nunca escribiría. 
Bulgákova.- También negará que en su obra La huida defiende a los enemigos de la Revolución.

BULGÁKov.-Soy un escritor, no un político.

BULGÁKOVA.- ¿Es usted apolítico? ¿De verdad cree que se puede ser neutral? Míreme cuando le hablo, Bulgákov. En un mundo dominado por la injusticia, la pretensión de ser imparcial ¿no será sencillamente cinismo? Míreme a los ojos, señor apolítico: ¿en serio cree que no tiene ninguna responsabilidad para con el pueblo?

Bulgákov.-Quiero ser útil a mi pueblo. Pero ¿cómo serlo si todos los teatros ejecutan, al unísono, una orden de Stalin: «No quede rastro de Bulgákov sobre la escena soviética»?

Bulgákova.- ¿Cómo puede decir eso? Soy su más fiel espectador. ¿Sabe que he visto quince veces Los días de los Turbín, ocho veces El apartamento de Zoika? Los aplausos que salían de mis manos resonaban por todo Moscú.

BULGÁkov.-Usted ha borrado mi nombre del teatro soviético. Me ha aniquilado.

Bulgákova.-Puedo recitar escenas enteras de sus obras. (Recita, ignorando a Bulgákov.) «iDimitri, los obreros están ensuciando con sus botazas el mármol de la escalera! ¿Quién ha quitado la alfombra? ¿Es que Marx prohíbe cubrir con alfombras las escaleras?...».

Bulgákov.-(Exaltándose.) Y ahora, como si mi destrucción fuera un objetivo largamente buscado, se regodea en mi aniquilamiento... (Deja de escribir y se encara con ella, que sige recitando.) ¡Presencia mi aniquilamiento con enorme felicidad! ¡Lo ha conseguido, camarada! ¡Que en este país no haya ni un rincón para una persona como yo!

\section{(Descubriendo que Bulgákov está fuera de sí, la mujer calla y abandona su fingimiento. Pausa.)}

Bulgákova.-Demos un paseo. (Lo toca con amor.) Todavía estará la orquesta en el bulevar. ¿Cuánto hace que no bailamos? (Lo invita a bailar. Pero él no la sigue.) Te conviene salir, Mijail. Ver gente.

Bulgákov.-No tengo ganas de ver a nadie, ni ganas de que nadie me vea. Gracias a la prensa de Stalin, todo Moscú me señala con el dedo. ¿Por qué me avergüenza así? ¿Por qué me humilla de este modo?

Bulgákova.-Olvidémonos de Stalin. No necesitamos su permiso para ser felices. 


\section{(Lo toca; quiere sacarlo a la calle. Pero Bulgákov vuelve a su carta.)}

BULGÁKov.-Usted ha conseguido que en la Unión Soviética no haya ni un pequeño rincón para una persona como yo.

(Aguarda la reacción de su mujer. Pero ella se resiste a ser otra vez Stalin.)

BulgÁKov.-Usted ha conseguido que en la Unión Soviética no haya ni un pequeño rincón para una persona como yo. Ha hecho de mí un fuera de la ley. Un criminal.

BUlgákova.-Disfruta chupándose las heridas, Bulgákov. ¿No es capaz de un solo pensamiento positivo?

Bulgákov.-Para mí, el no poder escribir es lo mismo que ser enterrado vivo.

BulgÁkova.-No exagere, Bulgákov. Seguro que podría hacer otro tipo de trabajo.

BULGÁKov.-Hasta hace un año, para no morirme de hambre, por la mañana enseñaba teatro en un colegio; por la tarde sustituía a los actores enfermos del Teatro de Stanislavsky; por la noche, a los del Teatro de la Juventud Obrera. Cuando volvía a casa, intentaba escribir, hasta que reventaba de cansancio... Hoy, ni siquiera se me considera digno de aquellos trabajos. Mi nombre se ha hecho tan odioso que mis solicitudes de empleo son acogidas con espanto. Directores, editores, todos se apartan de mí como de un apestado... Camarada Stalin, apelo a su humanitarismo. Si no puedo ser de ninguna utilidad a mi país, le pido que me autorice a abandonar la Unión Soviética en compañía de mi esposa... (Pausa. Ella no replica.) Pero si usted considera que debo vivir en la Unión Soviética... (Pausa. Ella no replica.) le pido libertad para publicar y representar mis obras... (Pausa. Ella no replica.) Si esto no fuera posible, le pido que me permita ser útil a mi país en calidad de director de escena. Me ofrezco con sinceridad, sin pretensión de sabotaje, para dirigir cualquier obra, desde obras griegas hasta actuales... (Pausa. Ella no replica.) Si esto tampoco fuera posible, pido que se me nombre ayudante de dirección... Si no fuera posible, pido un puesto de figurante... Si tampoco es posible ser nombrado figurante, pido un puesto de tramoyista.

(Silencio. La mujer medita.) 
Bulgákova.-No expresa usted su deseo con claridad. Si no sé lo que desea, ¿cómo voy a satisfacer su deseo? ¿Qué quiere de mí? ¿Que lo deje marchar o que le permita escribir lo que le venga en gana? ¿Está decidido a irse al extranjero... o prefiere permanecer en la Unión Soviética y en qué condiciones? ¿De verdad aceptaría un trabajo subalterno en el teatro? Si yo le ofreciese un puesto de acomodador en el Teatro de Stanislavsky, ¿renunciaría a emigrar?

Bulgákov.-Si ni siquiera de acomodador pudiese trabajar...

Bulgákova.- ¿Tiene usted las ideas claras, Bulgákov? Me preocupa su salud mental. Ustedes, los poetas, son gente tan vulnerable... No se me va de la cabeza el triste final del pobre Maiakovski. Y sólo hace unos días enterramos a Sóbol y a Esenin. En cuanto a su buen amigo Zamiatin, usted mejor que yo sabe en qué situación se encuentra. Si no quiere acabar como ellos, debería replantearse el modo en que está conduciendo su vida.

BULGÁKov.-Si ni siquiera se cuenta conmigo para limpiar los lavabos del más humilde teatro del país... Entonces pido al Gobierno Soviético que proceda conmigo como crea más conveniente. Pero que proceda de alguna manera.

Bulgákova.-Se expresa como si no tuviera nada que perder. ¿No tiene nada que perder?

Bulgákova.-Pero que proceda de alguna manera. Porque yo, un dramaturgo famoso en toda Europa, en mi propio país me encuentro abocado a la miseria y a la muerte...

(Le interrumpe el sonido del teléfono. Molesto, Bulgákov descuelga.)

Bulgákov.—¿Sí? (Silencio. Mira a su mujer.) Yo soy. (Silencio.) Buenas tardes, camarada. (Silencio.) Últimamente me he hecho mil veces la misma pregunta: ¿Puede un escritor ruso vivir fuera de su patria? (Silencio.) Claro que me gustaría, pero no he recibido más que negativas. (Silencio.) ¡Oh, sí, Iosif Visarionovich, tenemos que conversar! (Silencio. Está escuchando a su interlocutor cuando, bruscamente, la línea telefónica se corta. Silencio. Bulgákov cuelga.)

BULGÁKov.-Se ha cortado.

(Pausa. Bulgákov espera que el teléfono vuelva a sonar. Pausa.) 
(Bulgákov espera que el teléfono vuelva a sonar.)

Bulgákov.-No comprendo. Estaba a punto de darme fecha y hora. «¿Mijáil Afanásievich Bulgákov? Le habla el camarada Stalin». Imagínate mi sorpresa. «Buenas tardes, camarada Bulgákov. Hemos recibido sus cartas. Las hemos leído con los camaradas. Quiere marcharse al extranjero, ¿no es eso? Está harto de nosotros». Yo le respondí: «Últimamente me he hecho mil veces la misma pregunta: ¿Puede un escritor ruso vivir fuera de su patria?». A lo que él dijo: «También yo me hago muchas veces esa pregunta. Pero hablemos de usted. ¿Dónde le gustaría trabajar? ¿En el Teatro de Stanislavsky?». Inmediatamente contesté: «Claro que me gustaría, pero no he recibido más que negativas». Ahí fue cuando él dijo: «Presente una solicitud. Tengo la impresión de que esta vez la aceptarán». Y añadió: «Tendríamos que reunirnos para charlar». «iOh, sí, Iosif Visarionovich, tenemos que conversar!», dije yo sin dudarlo. A lo que él dijo: «Sí, vamos a encontrar un momento apropiado para eso». Y estaba consultando su calendario, buscando día para convocarme a su despacho, cuando se cortó.

(Pausa.)

Bulgákova.- ¿Estás seguro de que volverá a llamar?

Bulgákov.- ¿No te he dicho que estaba a punto de fijar un día y una hora? Acababa de decir: «Tendríamos que reunirnos para charlar».

(Pausa.)

Bulgákova.- ¿Por qué no le llamas tú?

BuLGÁKOV.—¿A Stalin? ¿Te has vuelto loca?

(Pausa. Bulgákov toma papel y pluma.)

BULGÁKOV.-Le escribiré recordándole mi disposición para acudir a esa cita. (Silencio.) ¿Preparada?

(No sin dudarlo, ella acepta ser Stalin. Bulgákov escribe.)

BULGÁKOV.—Estimado camarada... 
(Junto al teléfono, Bulgákov intenta escribir. Pero no puede hacerlo solo. Al rato entra su mujer, que viene de la calle.

Bulgákov está contrariado por su retraso.)

BULGÁKOVA.-(Quitándose la ropa de la calle.) Una cola espantosa. Todos los diciembres son igual, la gente se vuelve loca por enviar regalos a sus familias. Pero ya está, certificada, como querías. En seguida estará en manos de Stalin.

Bulgákov.-He pensado que, en lo sucesivo, deberías llevar personalmente las cartas al Kremlin. No podemos seguir confiando en el correo. (Se dispone a escribir.) ¿Preparada?

Bulgákova.- ¿A quién dirás que me he encontrado en la estafeta?

(A Bulgákov no le importa. Está impaciente por escribir.)

BulgákovA.-A nuestro amigo Zamiatin. Me acompañó de vuelta hasta el bulevar.

Bulgákov.- ¿Zamiatin paseándose por Moscú? ¿Después de todo lo que se ha dicho sobre él? Se arriesga a que la gente lo apedree. (Escribiendo.) Estimado Iosif Visarionovich: En los últimos diez años...

BulgákovA.-(Interrumpiéndole.) Zamiatin ha recibido respuesta positiva.

\section{(Conmoción de Bulgákov.)}

BulgákovA.-Zamiatin escribió a Stalin y, al cabo de una semana, recibió un oficio del Comité de Asuntos Extranjeros. Puede salir de la Unión Soviética tan pronto como lo desee.

(Pausa.)

BULGÁKOVA.- ¿ ¿No vas a ir a felicitarlo?

(Silencio.)

Bulgákova.-Ya, ya sé: tienes que quedarte junto al teléfono. Si ni para mandar tus cartas te asomas ya a la calle, ¿cómo vas a visitar a tu amigó? Tampoco puedes telefonearle. Nadie debe tocar este teléfono. Stalin puede llamar en cualquier momento. 
BULGÁKOV.- «Tendríamos que reunirnos para charlar», dijo. Me contó que había leído mis cartas con los camaradas. Sin duda se refería a Molotov y a los demás del Gobierno. «Quiere marcharse al extranjero, ¿no es eso?», me dijo.

Bulgákova.-Todo Moscú cuenta esa historia. Se la has contado a todo el mundo que ha pasado por aquí. Que Stalin te llamó y lo que hablasteis.

BulgáKOV.- ¿Te parece mal? ¿Está mal que la gente deje de verme como un apestado? Antes, yo era para todos un literato caído en desgracia, pero ahora muchos escritores me envidian. ¿A cuántos de ellos ha telefoneado Stalin? ¿A cuántos ha dicho: «Tendríamos que reunirnos para charlar»?

BulgáKova.-¿Estás seguro de que era él? ¿No sería un bromista?

Bulgákov.-¿Qué estás diciendo? Era él. Llevó la conversación como sólo puede hacerlo un hombre de Estado. Era él.

BulgáKOVA.—¿Y si no te volviese a llamar?

Bulgákov.-No puede ser. Tenemos mucho de que hablar. (Va a reanudar su carta.) Le recordaré que tenemos una cita pendiente. ¿Vas a ayudarme? ¿A buscar las palabras justas?

Bulgákova.-Zamiatin consiguió encontrarlas. ¿Por qué no las copias? Las palabras que Zamiatin escribió a Stalin.

BUlGákov.-¿Lo tomas por tonto? Stalin sabe muy bien quién es Zamiatin y quién es Bulgákov. Yo jamás escribiría con ese estilo ampuloso y dulzón de Zamiatin.

BulgáKova.-Es sólo una carta.

Bulgákov.- ¿Sólo una carta? Jamás he escrito nada tan importante. Mis comedias, mis novelas... ¿qué valor tienen frente a una carta así? Todo lo que he escrito es un juego de niños si lo comparo con una carta a Stalin. (Silencio.) ¿No vas a ayudarme?

(Pausa. La mujer acepta, una vez más, ser Stalin.)

Bulgákova.-Pero no llevaré tu carta al Kremlin ni a ningún otro lugar. Tendrás que llevarla tú mismo. ¿Te atreverás? ¿Te atreverás siquiera a acercarte al buzón de la esquina? ¿Recuerdas qué hay al otro lado de esa ventana?

(Obliga a Bulgákov a mirar hacia la calle.) 
BULGÁKovA.-Moscú, la ciudad que tanto amabas. Está preciosa esta tarde. ¿No quieres que demos un paseo por el bulevar, antes de que anochezca?

(Lo toca. Bulgákov parece tentado. Pero algo que ve por la ventana llama su atención. Su mujer le interroga: "¿Qué te

$$
\text { pasa?».) }
$$

Bulgákov.- Me había parecido... Al otro lado de la calle, entre los árboles. Me había parecido ver a Stalin.

(Junto al teléfono, varias cartas dispuestas para el envío. Bulgákov, pluma en mano. Ante él, su mujer representa a Stalin. Ella pega un puñetazo en la mesa ante Bulgákov.)

Bulgákova.- ¿Basta ya, Bulgákov, ni una palabra más! Estoy harto de leer siempre la misma carta. Distintas palabras, pero siempre el mismo gesto aristocrático, antisocial. $\mathrm{Ni}$ el menor atisbo de arrepentimiento. No vuelva a escribirme si no es para reconocer que malgasta su talento poniéndolo al servicio de espectadores degenerados. Su obra rezuma desprecio hacia el orden soviético, niega todos los logros de la Revolución. Sólo trata temas que no conviene abordar y enmascara sus ataques bajo burdas metáforas... (Stalin entra en escena; observa cómo la mujer lo imita.) En Los huevos fatales, por ejemplo. Ahí presenta el territorio soviético invadido por reptiles de doce metros. Nada puede detener a los reptiles. Ni siquiera, esto lo deja usted muy claro, ni siquiera el Ejército Rojo puede detenerlos. ¿Se trata de una alegoría? ¿Pretende usted comparar a los bolcheviques con...? Ni una carta más, Bulgákov. Decida de una vez: ¿de qué lado de las barricadas está? Ni una carta más si no es para expresar, con toda claridad, que está con nosotros o contra...

(Se interrumpe al oír que alguien llama a la puerta. Abandona su fingimiento y sale a abrir. Bulgákov observa a Stalin, que se mueve por el lugar, explorándolo. La mujer vuelve.)

BULGÁKovA.-Zamiatin. Ha venido a despedirse. 
(Bulgákov calla.)

Bulgákova.-Ya le he dicho que últimamente no recibes a nadie. Pero él insiste en darte un abrazo antes de partir hacia Berlín. ¿Le hago pasar?

\section{(Bulgákov calla.)}

Bulgákova.-Quiere hablarte de la carta que él escribió a Stalin. Explicarte qué razones manejó para que Stalin lo dejase salir.

BULGÁKOV.-Puedo imaginar qué razones habrá manejado, y cómo las habrá manejado, conozco muy bien a Zamiatin. Pertenece a esa clase de escritores que igual componen un poema que rellenan una instancia. (Silencio.) Pero me alegro de que su suerte haya cambiado, díselo. Seguro que saldrá adelante en el extranjero, él siempre acaba saliendo adelante. Dile que tengo mucho trabajo.

\section{(Pausa.)}

Bulgákova.-Así pues, ¿lo despido?

(Bulgákov asiente. Ella sale. Bulgákov y Stalin se observan. La mujer vuelve, con la emoción que le ha provocado la despedida de Zamiatin.)

BULGÁKOVA.- Ya está: se ha ido. Espera encontrarse contigo algún día en algún lugar del mundo. Te ha dejado esto.

(Pone un papel ante Bulgákov.)

BulgáKova.-La carta que él escribió a Stalin.

(Bulgákov ignora el papel. Su mujer lo toma para leérselo en voz alta.)

BULGÁKOVA.—«Estimado Iosif Visarionovich: condenado a un castigo mortal, me dirijo a usted para pedirle que me sea conmutada esa pena. Para un escritor, la imposibilidad de escribir constituye un castigo mortal. Sé que debo ese castigo a mi mala costumbre de escribir no lo que podría serme útil, sino lo que creo que es verdad. Considero que el servilismo rebaja tanto al artista como a la Revolución...».

(Viendo el interés de Stalin por la carta de Zamiatin, Bulgákov empieza a leerle la que él estaba escribiendo: «Muy estimado Iosif Visarionovich: En todas mis obras la prensa oficial ha detectado una intención diabólica. La aparición de mi firma 
basta para calificar cualquiera de mis escritos como demoniaco.

Escupir al diablo se considera una buena acción, y nadie se priva de hacerlo...». Las voces de Bulgákov y de su mujer se confunden, impidiendo entender la totalidad de ambas cartas.

Bulgákov calla cuando comprende que Stalin está más interesado en la de Zamiatin.)

Bulgákova.— «... Durante tres años trabajé en una tragedia. La leí en el Consejo Teatral de Leningrado a representantes de dieciocho fábricas. El representante de la fábrica de textiles dijo: «Esta obra trata el tema de la lucha de clases en la antigüedad». El representante de la fábrica de hidromecánica sentenció: «Esta pieza es una síntesis dialéctica de Shakespeare y Marx». El Consejo aprobó unánimemente la representación de mi tragedia. Sin embargo, ¿se ha permitido ver mi obra a ese público obrero que le dio su aprobación? Nunca. Porque contra un condenado a muerte cualquier argucia está permitida. Mi novela Nosotros, escrita hace nueve años, fue presentada por los críticos como mi último trabajo. Ello sirvió de excusa para prohibir en pleno éxito las representaciones de mi obra La pulga...».

(Buscando la atención de Stalin, Bulgákov abre una de las cartas ensobradas y lee: "Estimado Iosif Visarionovich: Me permito dirigirle esta solicitud para redactar una guía de viajes de Europa Occidental. A fin de justificarla, le informaré acerca de algunos sucesos que me han acontecido en el último año y medio...». Pero a Stalin le interesa más la carta de Zamiatin, así que Bulgákov deja de leer.)

Bulgákova.—《... Está prohibida la exhibición de mis libros en las bibliotecas. Incluso se me prohíbe traducir. Cualquier editorial interesada en mis trabajos se expone al fuego. S6́lo la editorial «Tierra y Fábrica» se arriesgó a encargarme la corrección estilística de escritores jóvenes, y está pagando por ello. Doy miedo a las editoriales, a los teatros, incluso a mis amigos doy miedo. Se han cerrado todas las puertas que me permitían llegar al público. Lo que supone tanto como mi sentencia de muerte. Pero el código penal soviético prevé un castigo peor que la muerte: el exilio. Si soy un criminal, pido ser expulsado de la Unión Soviética. Si no soy un criminal, pido permiso para viajar al extranjero. Regresaré cuando en nuestro país sea posible hacer arte sin tener que servir de lacayo de personas insignificantes. Ese momento no tardará en llegar, porque, después de haber creado una base material, se planteará de forma 
ineludible la creación de una superestructura, un arte digno de la Revolución...»

(Luchando por la atención de Stalin, Bulgákov abre otra de las cartas ensobradas: "Muy estimado Iosif Visarionovich: Muchos de mis colegas han sido condenados a vivir en las ciudades de Ieniseisk, Tomsk y Kalinin. A mí se me permite vivir en Moscú. Sin embargo, también yo padezco una forma de exilio. No me es posible respirar en una atmósfera de acoso sistemático que se refuerza día tras día. Me dirijo a usted para pedirle que suavice mi destino...». Bulgákov deja de leer, pues Stalin sólo tiene oídos para la carta de Zamiatin.)

Bulgákova.— «... Sé que la vida en el extranjero no me resultará fácil. En la Unión Soviética, debido a mi costumbre de escribir según mi conciencia, se me considera un reaccionario; en el extranjero, por esa misma causa, me tildarán de comunista. Pero allí no me condenarán a guardar silencio. Podría basar mi solicitud en otros motivos: una enfermedad cuyo tratamiento sólo es posible en Alemania; la puesta en escena en Italia de mi obra La sociedad de los compañeros honoríficos... La verdadera razón de mi solicitud es la sentencia de muerte que la Unión Soviética ha pronunciado contra mí como escritor. Para recobrar la libertad como artista, no dudaré en renunciar a aquello que, después de esa libertad, más amo: mi país. Firmado: Evgueni Ivánovich Zamiatin. Moscú, junio de 1931».

\section{(Largo silencio.}

Meditabundo, Stalin sale de escena.

Pausa. Bulgákov se vuelve hacia su mujer.)

Bulgákov.- ¿Has estado usando el teléfono en mi ausencia?

Bulgákova.-Tú siempre estás aquí, junto al teléfono.

BuLgÁKov.-Aquella vez que dijiste estar enferma y tuve que ir yo al buzón. ¿Usaste el teléfono en aquel momento?

Bulgákova.-Sé que no puedo usar el teléfono.

BULGÁKov.-No entiendo por qué no me llama. Tenía muchas ganas de hablar conmigo. Desde el principio, su tono fue cordial, como el de quien se propone iniciar una larga y profunda relación: «Hemos recibido sus cartas. Las hemos leído con los camaradas. Quiere marcharse usted al extranjero, ¿no es eso? Está harto de nosotros». Cuando yo le dije que una y otra vez volvía a mi cabeza la pregun- 
ta de si un escritor ruso puede vivir fuera de su patria, contestó que también él se preguntaba eso a menudo. En aquel momento me ofreció un puesto en el Teatro de Stanislavsky. «Presente una solicitud», dijo. «Tengo la impresión de que esta vez la aceptarán». Lo que, viniendo de Stalin, equivalía a una promesa. Y añadió: «Tendríamos que reunirnos para charlar». Estaba preguntándose cuál sería el momento más apropiado para nuestro encuentro cuando el maldito telefóno nos jugó una mala pasada.

BulgáKova.-Lo sé.

BULGákov.-Tenía unas ganas enormes de encontrarse conmigo.

Bulgákova.—Ya sé.

BuLGáKov.-Tendrías que haber oído en qué tono se presentó: «Le habla el camarada Stalin». En el mismo tono afectuoso, dijo: «Hemos recibido sus cartas. Las hemos leído con los camaradas. Quiere marcharse usted al extranjero, ¿no es eso? Está harto de nosotros». Ahora no estoy seguro de si dijo «marcharse al extranjero» o «ir al extranjero». ¿O dijo «salir al extranjero»? Debería recordar los términos con precisión. Cambiando una palabra, se cambia el sentido. Algo me llevó a responderle: «Últimamente me he hecho mil veces esa pregunta: ¿Puede un escritor ruso vivir fuera de su patria?». A lo que él, con cierto asombro, respondió: «A menudo yo me hago la misma pregunta. Bulgákov, ¿sabe que soy un fiel espectador suyo? ¿Sabe que puedo recitar escenas enteras de sus obras? Desde hace tiempo tengo la impresión de que usted y yo podríamos llegar a entendernos. Tendríamos que reunirnos para charlar». En ese momento se cortó.

(Pausa.

Bulgákov toma papel y pluma.)

BulgáKova.- ¿Otra carta, Mijail? ¿Crees que una carta más nos sacará del infierno?

(No hay respuesta. Bulgákov escribe.)

BulgáKova.-Mañana iré al Teatro de Stanislavsky. Deben de estar a punto de salir en su gira anual por Europa. Les pediré que hagan algo por ti: les pediré que escriban nuestros nombres en la lista de actores que viajarán al extranjero. Son tus amigos. No puede serles indiferente tu suerte.

(No hay réplica. Bulgákov escribe.) 
Bulgákova.—¿No vas a leérmela?

(No hay respuesta. Bulgákov escribe.)

Bulgákova.-Léemela. Te ayudaré. Haré como que soy Stalin.

(No hay respuesta. Ella lo toca, pero Bulgákov ya no siente sus manos.)

(Las cartas ensobradas se acumulan. Bulgákov, solo, escribe.)

Bulgákov.-Estimado Iosif Visarionovich. Cuando a un hombre se le acosa como a una fiera, acaba actuando como una fiera.

(Silencio. Bulgákov se comporta como si viese y oyese a alguien a quien sólo él oye y ve.)

BULGÁKov.-Se puede acosar a una fiera hasta que su corazón reviente. Pero justo entonces la fiera será más peligrosa que nunca.

(Silencio. Bulgákov se comporta como si viese y oyese a alguien a quien sólo él oye y ve.)

BulgáKov.-Desde 1930 sufro estados de angustia cardiaca.

(Stalin en escena. Se comporta ante Bulgákov como lo hacía la mujer cuando ella representaba a Stalin. Bulgákov escribe.)

STALIN.- ¿Está usted enfermo? ¿Me permitirá que le envíe a mi médico personal? Un buen hombre, georgiano.

Bulgákov.-La causa de mi enfermedad es el silencio a que se me ha reducido durante años.

STALIN.-Ah, se refería a esa clase de enfermedad.

Bulgákov.-Después de tanto callar, se agitan en mí nuevos proyectos creativos. Pero carezco de fortaleza física para llevarlos a cabo. Estoy agotado.

Stalin.-Se merece un descanso, camarada. No abuse de sus fuerzas. 
BulGÁKOv.-Usted sabe que en la Unión Soviética no se me deja descansar. Le ruego que interceda ante el Gobierno... A fin de que me conceda una licencia para salir al extranjero.

(Stalin calla.)

Bulgákov.-Todo lo que necesito es descansar fuera de la Unión Soviética durante unos meses.

\section{(Stalin calla.)}

BulgáKov.--Incluso podría serme suficiente una semana fuera de la Unión Soviética.

(Stalin calla. Bulgákov aguanta su silencio.)

Stalin.-Durante años, muchas personas, del partido y de fuera del partido, se han acercado a usted con la mejor voluntad. Para advertirle que cada renglón que salía de su pluma le granjeaba problemas en la Unión Soviética tanto como le cerraba la puerta del extranjero. Usted ha desoído todas esas recomendaciones.

BulgÁKov.-Amigos y enemigos me aconsejan que me tiña la piel. Absurdo consejo. Un lobo, por mucho que se tiña, nunca se parece a un caniche. Por eso se me acosa como se acosa a las fieras. Como fiera que soy, nunca callaré. Un artista que calla no es un verdadero artista.

STALIN.-Usted mismo se condena, camarada Bulgákov. Usted mismo se cierra el horizonte.

Bulgákov._¿Estoy preso en la Unión Soviética? ¿Cómo voy a escribir canciones a un país que es para mí una cárcel?

STALIN.-El crítico del Pravda ha escrito: «Bulgákov no es necesario para este país». Yo me pregunto: Y Bulgákov, ¿no necesita él de este país? ¿No es para Bulgákov este país tan necesario como el aire? Camarada, en el extranjero usted se moriría de pena.

BULGÁkov.-Si se me permitiese salir, aunque fuese un solo día, volvería a mi patria cantando.

Stalin.-Los que nos interesamos por su trabajo, creemos impensable que pueda usted vivir en cualquier otro lugar. Su escritura se nutre de esta tierra.

BULGÁKov.-Veré qué hay al otro lado de la frontera y regresaré. 


\section{(Stalin niega.)}

BULGÁKov.-Necesito salir de la Unión Soviética, aunque sólo sea por una hora.

\section{(Stalin niega.)}

BULGÁKov.-A cambio, prometo convertirle a usted en mi primer lector. Igual que el zar Nicolás era el primer lector de los escritos de Pushkin. Una hora, es todo lo que le pido.

STALIN.- ¿Ha pensado que la puerta podría cerrarse bruscamente a sus espaldas? No poder regresar, ¿no sería para usted una desgracia mucho peor que la prohibición de sus obras?

BULGákov.-Sólo unos minutos. ¡Unos minutos! ¡Pisar un suelo donde me sienta libre!

(Bulgákov no se ha percatado de la entrada de la mujer, que viene de la calle.)

BULGÁKOVA.—¿Con quién hablas?

BULGákov.-Con nadie.

(Pausa larga.)

Bulgákova.—¿No me preguntas de dónde vengo?

(Silencio.)

Bulgákova.-Vengo del Teatro de Stanislavsky.

(Silencio.)

BULGÁKovA.-Están preparando su gira anual. En la pizarra hay escritos treinta nombres: la lista de los actores que viajarán al extranjero. Les pedí que añadiesen nuestros nombres.

STALIN.-(A Bulgákov.) ¿Piensas que consiguió convencerles?

BULGÁKOV.-¿Los convenciste?

BulgákovA.-Son viejos amigos tuyos. Has escrito cientos de páginas para ellos.

STALIN.- (A Bulgákov.) ¿No pidieron nada a cambio? ¿Nada de nada?

BULGÁKov.—¿Pidieron algo a cambio?

Bulgákova.-Todo lo que tenían que hacer era escribir dos nombres 
más en su pizarra. (Pausa.) Les tendí la tiza uno a uno. (Pausa.) Nikolai, tu protagonista en Los días de los Turbín, me contestó: «¿Por qué no van ustedes al Comité de Asuntos Extranjeros, como todo el mundo?». Ninguno quería coger la tiza. Konstantin fue el último al que se la tendí. Dijo: «¿Bulgákov?». Y escupió en el suelo.

\section{(Pausa.)}

Bulgákov.-Has hecho mal en ir allí. Ése no es el camino correcto. No entiendes nada, ¿cómo tendré que explicártelo para que lo entiendas? ¿Tendré que contártelo un millón de veces? «Le habla el camarada Stalin», dijo. «Hemos...».

BULGÁKovA.-(Interrumpiéndole.) «Hemos recibido sus cartas. Las hemos leído con los camaradas. Quiere marcharse al extranjero, ¿no es eso? Está harto de nosotros». Tú le respondiste: «Últimamente me he hecho mil veces la misma pregunta: ¿Puede un escritor ruso vivir fuera de su patria?».

Bulgákov.-Él no esperaba que yo le saliese por ahí. A partir de ese momento, llevé la conversación por donde me dio la gana. Por salir del paso, dijo: «También yo...»

BulgáKOVA.-(Interrumpiéndole.) «También yo me hago muchas veces esa pregunta. Pero hablemos de usted. ¿Dónde le gustaría trabajar? ¿En el Teatro de Stanislavsky?».

Bulgákov.-Como yo me esperaba algo por el estilo, contesté...

Bulgákova.- (Interrumpiéndole.) «Claro que me gustaría, pero no he recibido más que negativas».

BuLGÁKov.-Ahí fue cuando él tiró la toalla.

BulgÁKovA.— «Presente una solicitud. Tengo la impresión de que esta vez la aceptarán. Tendríamos que reunirnos para charlar. Habrá que encontrar un momento apropiado para eso».

(Pausa.)

BulgákovA.-Mañana iré al Comité de Asuntos Extranjeros. Solicitaré un permiso para viajar en compañía de mi marido.

BULGÁKov.-Imagino las caras de los funcionarios en cuanto sepan quién es tu marido.

Bulgákova.-Quizá no me pregunten quién es mi marido. 
BULGÁKov.-No necesitan preguntártelo. Imagino sus risas en cuanto lean tu solicitud.

Bulgákova.-No reirán. De mí no se reirán.

BULGÁKOV.-Ése no es el camino correcto.

(Bulgákov vuelve a la pluma y al papel.)

Bulgákova.—¿Cuál es el camino correcto? ¿Escribir un millón de cartas a Stalin?

(Bulgákov escribe. Stalin se sitúa entre él y ella.)

Bulgákova.-¿Y si le escribiese yo?

Bulgákov.-No te metas en esto.

Bulgákova.-Conmigo no jugará como juega contigo.

Bulgákov.-¿De qué hablas?

BulgáKova.-Está jugando contigo.

BulgÁKov.-¿Está jugando conmigo? No sabes lo que dices. Quería recibirme personalmente. Quería preguntarme acerca de los problemas del pueblo ruso.

Bulgákova.-Hablas de él como si fuera el buen zar de los cuentos.

BulgÁKov.-Quería conocer mis opiniones sobre el curso que está tomando la Revolución. Quería oírme hablar.

Bulgákova.-_Quería oírte hablar? Prohíbe la representación de tus obras; no te deja publicar una línea. ¿Y dices que quería oírte hablar? Quería tu silencio. No te llamó para que hablases, sino para cerrarte la boca.

Bulgákov.-_Me llamó para cerrarme la boca? Cómo se ve que no lo conoces. Es capaz de recitar escenas enteras de mis obras. Sé cuánto me aprecia.

Bulgákova.- ¿Te aprecia? ¿Sabes lo que su gente anda diciendo sobre ti en cada rincón de Moscú? Por toda la ciudad, todo el mundo me mira como si estuviese casada con el mismísimo demonio. Eso es obra de Stalin. Que todos escupan el suelo que piso, eso se lo debes a Stalin.

(Bulgákov no quiere seguir oyéndola. Para no oírla, escribe. Ya no la oye, aunque ella todavía mueve la boca.) 
(El montón de cartas ensobradas ha seguido creciendo. Bulgákov intenta escribir una más, pero parece bloqueado. Hasta que ve a Stalin, quien ya se mueve muy cómodo por el lugar.)

BULGÁKOV.-Ya pensaba que no iba a venir.

Stalin.-Son días de mucho trabajo, Mijail.

BULGÁKov.-Ayer ni siquiera apareció por aquí. ¿Cuánto tiempo será esta vez? ¿Diez minutos? ¿Cinco minutos?

STALIN.-Cada día tengo que hacer docenas de llamadas, que leer miles de cartas... No perdamos un segundo, veamos qué tenemos para hoy. (Bulgákov le da la última carta; Stalin lee.) «En los tiempos que corren, resulta difícil alcanzar un estado de ánimo tranquilo, tal y como es necesario para la ejecución de cualquier obra armoniosa. El presente tiene en Rusia un carácter demasiado movedizo, demasiado irritante. Siempre supe que me esperaba en la vida un gran sacrificio, y que, para ser útil a mi patria, debería escribir lejos de ella. Siempre supe que sólo conocería el valor de Rusia fuera de Rusia, y que sólo obtendría su amor estando lejos».

(Pausa.)

STALIN.- ¿No es un poco pedante?

Bulgákov.-No es mío. Son palabras de Gógol.

STALIN.-Nikolai Gógol... Eran otros tiempos... Por entonces, los escritores sabían interpretar lo que el pueblo necesitaba de ellos. Otros tiempos. Lenin prefería a Tolstoi, pero también a Gógol lo incluyó. Es el número cinco de la lista.

Bulgákov.—¿La lista?

STALIN.-El camarada Lenin agonizaba cuando, con un gesto, me señaló entre los camaradas que rodeábamos su lecho. Con sus últimas fuerzas, me tendió un papel: (Lo saca; lee.) «Lista de escritores a los que se debe levantar monumento en la ciudad de Moscú». Acto seguido, expiró.

(Pausa. Bulgákov no puede disimular su interés por la lista de

Lenin. Stalin se la leerá morosamente, jugando con la curiosidad de Bulgákov, que intenta adivinar los nombres y los comenta con gestos.) 
Stalin.-1. Tolstoi. 2. Dostoievski. 3. Lérmontov. 4. Pushkin. 5. Gógol. 6. Belinski...

Bulgákov.—¿Belinski?

STALIN.-... 7. Radischev. 8. Dobroliúbov. 9. Písarev...

Bulgákov.-Písarev. ¡Y Dobroliúbov!

(Stalin deja la lista a Bulgákov para que éste acabe de leerla.)

Bulgákov.-10. Mijailovski. 11. Uspenski. 12. Nekrásov.

(Pausa. Stalin lleva a Bulgákov ante la ventana.)

STALIN.-Moscú está preciosa esta tarde. No hay cielo como éste en ningún lugar del mundo. Sé cuánto amas esta ciudad, Mijail. ¿Te gustaría entrar en la lista de Lenin? Todavía hay sitio en Moscú para una estatua de Mijail Bulgákov.

(Stalin toma la pluma de Bulgákov, dispuesto a añadir su nombre a la lista: "13...». Para romper la tentación, Bulgákov recupera su pluma y vuelve a escribir.)

BULGÁKov.-Muy estimado Iosif Visarionovich...

STALIN.—¿Qué tal una estatua de Mijail Bulgákov en el bulevar?

Bulgákov.-Igual que a Gógol, también a mí la realidad de mi patria...

STALIN.-Tal y como estás ahora, pluma en mano. En bronce de Omsk.

Bulgákov._... La realidad de mi patria me aniquila como escritor y como hombre. Quizá tenga que renunciar a mi patria para sobrevivir como escritor y como hombre.

Stalin.-Repite eso.

Bulgákov.-«Igual que a Gógol, también a mí...».

STALIN.-Más adelante. La última frase.

BULGÁKOV.—《Quizá tenga que renunciar a mi patria para sobrevivir como escritor y como hombre».

STALIN.-Ésa no es la palabra. Esa palabra: «Quizá». Esa palabra no es tuya.

(Bulgákov no sabe con qué palabra sustituirla.) 
StALIN.-Vuelve a leerlo.

BULGÁKOV.-《Quizá tenga que renunc...».

STALIN.-(Interrumpiéndole, dictando.) Renunciaré a mi patria para sobrevivir como escritor y como hombre.

(Silencio. Bulgákov vacila. No sin miedo, escribe. No sin miedo, lee para sí lo que ha escrito.)

STALIN.-Éste es el momento. Ahora has de atacar. Ahora has de presentar tu deseo. (Dictando.) Pido al Gobierno de la Unión Soviética que me señale día y hora para...

BULGÁKov.—(Escribiendo. ) ... cruzar la frontera... en compañía de mi esposa.

Stalin.- ¿Por qué siempre has de mencionar a esa mujer?

BULGÁKov.-(Escribiendo.) Sufro un agotamiento del sistema nervioso. Necesito que mi esposa me acompañe.

StALIN.- ¿De verdad crees que te ayudará tenerla a tu lado? No parece el tipo de mujer que ayuda a vivir a un hombre. Mírala, precisamente ahí viene. En la cara se le ve que trae buenas noticias. ¿Será algo referente al Comité de Asuntos Extranjeros? ¿Habrá obtenido una respuesta a su solicitud? Ya sabes, lo de vuestro viaje.

(Entra la mujer. Viene de la calle, muy cansada.)

BULGÁKOVA.-Dijiste que no era el camino correcto. Que se reirían de mí, eso dijiste. Ni una sonrisa, ¿me oyes? Un funcionario recogió la solicitud, le puso un sello encima y dijo muy serio: «Vuelva usted el día catorce». Ni media sonrisa. Aunque es verdad que, el día catorce, después de recorrer todas las ventanillas sin encontrar a aquel funcionario... Por un momento, pensé que estabas en lo cierto, que ni siquiera habían leído mi solicitud. Estaba a punto de volverme a casa cuando se me acercó otro funcionario, que me dijo: «Diríjase a la tercera ventanilla y rellene un impreso para usted y otro para su marido. Conviene que lo haga cuanto antes, pues no se dará respuesta a ninguna solicitud después del día veintiuno.»

STALIN.— ¿Quién era ese funcionario?

BULGÁKOV.—¿Quién era ese funcionario?

Bulgákova.-No lo sé. 
STALIN.—¿No se informó?

BulgáKov.- ¿No te informaste? (A Stalin:) No se informó. (A ella.) ¿Hablaste con él sin saber quién era?

BULGÁKOVA.--Estaba impaciente por conseguir nuestro permiso. Me dirigí a la tercera ventanilla. Pero allí no encontré a nadie. Estaba pensando que me habían gastado una broma y que más valía volverse a casa, cuando el funcionario de la quinta ventanilla hizo una seña al de la cuarta para que me atendiese. Éste fue el más amable de todos. Ni media sonrisa. Desapareció por una puertecita y a los veinte minutos volvió con unos formularios para que los rellenase. Con mucha paciencia, me explicó las preguntas que me costaba entender. Una vez rellenados los cuestionarios, los tomó y pegó en ellos dos fotografías.

Stalin.- ¿Tenía vuestras fotografías? ¿También la tuya, Mijail?

BULGÁKOV.-Así que tenía nuestras fotografías...

BULGÁKOVA.—Hice gesto de ir a pagar, pero me detuvo diciendo: «Los pasaportes serán gratuitos».

STALIN.-Con que gratuitos.

Bulgákova.-Le tendí los carnets de identidad, pero él dijo: «Eso luego, cuando sean intercambiados por los pasaportes». $Y$ añadió: «Los pasaportes los recibirá en seguida, en cuanto se suspenda la disposición especial que hay respecto a ustedes. Pero ya es tarde para que lleguen hoy. Vuelva el dieciocho por la mañana». Yo le dije: «Pero el dieciocho es fiesta». Él respondió: «Entonces, el diecinueve».

Stalin y Bulgákov.-Y tú volviste el diecinueve.

(Stalin y Bulgákov escuchan con creciente desprecio el relato de la mujer. Ella lucha por la atención de Bulgákov.)

BULGÁKOVA.-Llegué antes de que abriesen. El funcionario de la quinta ventanilla me hizo una seña para que me acercase. Ni media sonrisa, Mijail. Me dijo lo siguiente: «Sus pasaportes llegarán hoy. Vuelva dentro de un rato. Puede darse un paseo, para entretenerse». Pero yo preferí quedarme en la sala de espera. Hasta que, a última hora, otro funcionario se asomó para informarme en voz alta de que los pasaportes no estarían antes del día veintitrés.

Stalin.- ¿No es hoy día veintitrés? Ya no sé ni en qué día vivo. 
Bulgákova.-Así que hoy, nada más levantarme, me he ido al Comité. Los pasaportes no estaban. Reconozco que se me ha pasado por la cabeza: «Mijail tenía razón. Éste no es el camino correcto». Pero un funcionario se ha interesado por mi caso, ha hecho cuatro llamadas y me ha indicado que volviera el veinticinco o el veintisiete. Le he preguntado si había alguna disposición especial sobre nosotros. Él me ha respondido muy discretamente: «Comprenderá que no puedo decirle de quién proviene la disposición, pero tal disposición sobre usted y su marido existe. Sin embargo, no debe preocuparse. También existió una disposición similar sobre el escritor Zamiatin». Ni media sonrisa, Mijail. Así que he salido muy animada de allí. En las escaleras, he oído a un funcionario que decía a otro: «El asunto de los Bulgákov se está arreglando». El otro contestó: «Se arreglará como se arregló lo de Zamiatin». En el vestíbulo, unas limpiadoras me han felicitado. Hasta ellas había llegado el rumor de que por fin vamos a realizar el viaje con que durante tanto tiempo hemos soñado.

\section{(Pausa.)}

BulgÁKova.-Dijiste que se reirían de mí y ya ves. Ni media sonrisa. Sólo tenemos que esperar unos días más.

\section{(Pausa.)}

Bulgákova.- ¿ ¿O es que lo he entendido todo mal desde el principio?

STALIN.-Claro que lo ha entendido todo mal. Desde el principio. Desde la primera ventanilla. Incluso desde antes. Bueno, Mijail, ¿dónde estábamos?

BulgÁKov.— «Pido al Gobierno de la Unión Soviética que me señale día y hora para cruzar la frontera en compañía de mi esposa».

(Stalin dicta; Bulgákov escribe.)

STALIN.-Punto y aparte. Si son necesarias explicaciones complementarias a esta carta, estoy dispuesto a dárselas a usted personalmente... De hecho, no quiero terminar sin decirle, Iosif Visarionovich, que mi mayor deseo es ser recibido personalmente...

BULGÁKOVA.-(Interrumpiéndole, consiguiendo que Bulgákov la mire.) Hay otros caminos. El mercado negro. Dicen que allí se pueden comprar papeles falsos. Pero es peligroso, dicen. ¿Me acompañarás? 
(Pausa. Bulgákov desvía su mirada hacia Stalin y escribe a su dictado.)

StALIN.-... que mi mayor deseo es ser recibido personalmente por usted. La conversación telefónica que sostuvimos en abril de 1930 ha dejado profunda huella en mi memoria...

BulgÁKova.-(Sobre la voz de Stalin.) ¿Me acompañarás? (Buscando la mirada de Bulgákov, se sitúa entre él y Stalin. Pausa.) Me da miedo dejarte solo. Es como si esta casa estuviese endemoniada. Como si el demonio estuviese suelto por la casa.

(Bulgákov deja de escribir. Mira a la mujer.)

Bulgákov.-Como si el demonio estuviese suelto por la casa.

STALIN.-(Dictando.) Quedé hondamente impresionado...

$$
\text { (Bulgákov no le sigue.) }
$$

Bulgákov.-(Para sí.) Como si el demonio estuviese suelto por la casa.

Stalin.-Vamos, Mijail, no te distraigas. (Dicta.) Quedé hondamente impresionado...

Bulgákov.-(Para sí.) Como si el demonio estuviese suelto...

STALIN.-(Interrumpiéndole, le dicta al oído.) ... hondamente impresionado por las palabras que entonces me dirigió...

BulgáKova.-(Sobre la voz de Stalin.) Te sacaré de aquí, Mijail. Conseguiré esos pasaportes. Te sacaré de este infierno.

STALIN.-Déjala que lo intente.

$$
\text { (Bulgákov ve salir a la mujer.) }
$$

Bulgákov.-(Para sí.) Como si el demonio...

(Stalin toma la mano de Bulgákov para obligarle a seguir escribiendo.)

Stalin.-Si quiere usted responderme por escrito, ya sabe que mi dirección es: Moscú, Bolshaya Piorgovskaya 35, apartamento 6. Pero si prefiere telefonearme, le recuerdo que mi número sigue siendo el 520327. Me haría enormemente feliz reanudar nuestra conversación. Firmado: Mijail Bulgákov, Moscú... (Deja de escribir.) ¿Qué día es hoy? 
(No hay réplica. Bulgákov toma papel blanco.)

Bulgákov.-(Para sí.) Como si el demonio estuviese suelto por la casa.

(Bulgákov escribe.)

(Stalin escribe.)

Stalin.-... Antes de molestarle una vez más, lo he sopesado todo.... La respuesta positiva que dio a mi amigo Zamiatin me permite albergar la esperanza... de que también mi petición será escuchada... (Deja de escribir, molesto por la falta de atención de Bulgákov.) ¿Qué te pasa, Mijail?

(Bulgákov descubre a Stalin.)

BulgáKov.-(Distante.) No le había visto. No sabía que estaba usted aquí.

STALIN.- ¿No te alegras de verme?

BULGÁKov.-Es sólo que he pasado una mala noche. ¿No podríamos tomarnos un día de descanso?

STALIN.- ¿Un día de descanso, con todo lo que tenemos que hacer? (Pone ante Bulgákov la pluma y el papel.) ¿Por dónde íbamos? Léeme por dónde íbamos.

BulgÁKOV.- «La respuesta positiva que dio a mi amigo Zamiatin, me permite albergar la esperanza de que...».

STALIN.—Quita «esperanza». Pon «certeza». ¿Cómo queda?

BulgÁKOV.—《... me permite albergar la certeza de que también mi petición será escuchada».

STALIN.-... de que también mi petición será respondida positivamente. Lo que le pido es que, sin más rodeos, me haga saber qué espera de mí. Le pido luz acerca de mi futuro... (Deja de dictar.) No, no, tacha eso... (Dicta.) Le pido una orden categórica. Lo pido como última instancia... (Deja de dictar.) Eso es. Ése es el tono... ¿Qué es lo que ocurre, Mijail? 
BULGáKov.-Preferiría dejarlo por hoy.

(Silencio.)

Stalin.-Así que quieres que me vaya. Muy bien. Todos necesitamos estar solos de vez en cuando. (Silencio.) No me estarás ocultando algo.

(Lo mira fijamente. Hasta que Bulgákov le muestra unos folios manuscritos.)

STALIN.— ¿Una novela? ¿La segunda parte de La guardia blanca?

(Bulgákov niega. Stalin hojea los folios.)

STALIN.- ¡Una obra de teatro! ¡Cinco escenas en una sola noche! Porque lo has escrito esta noche, ¿verdad? Así que ahora escribes de noche, como el diablo. Se te ocurrió un argumento y escribiste cinco escenas sin parar, por eso no has pegado ojo. Ya sabía yo que me ocultabas algo. (Descubre algo en los folios.) Y trata sobre el diablo, ¡qué interesante! (Mira de reojo a Bulgákov.) Vamos, Mijail, cuando a un escritor se le ocurre un argumento, se pone la mar de alegre. ¿Cómo es que tú estás triste?

Bulgákov.-Los teatros de la Unión Soviética no van a querer mi obra, Iosif Visarionovich.

Stalin.- ¿Cómo que no? ¿Dónde te gustaría que se representase tu obra?

BULGáKov.-Por querer, en el Teatro de Konstantin Stanislavski.

Stalin.-Pues ahora mismo voy a llamarle. Precisamente he pasado esta tarde por allí y me he indignado al no ver en cartel ninguna obra tuya.

BULGÁKOV.— ¿Va a hacer que estrenen mi obra?

Stalin.-Está hecho. Déjame que haga una llamada. (Toma el teléfono. Marca.) Tú tranquilo, Mijail, siéntate. (Al teléfono.) Señorita, señorita, ¿me escucha? ¿Es ahí el Teatro de Stanislavsky? (Lanza una mirada a Bulgákov.) Póngame con el camarada Konstantin Stanislavsky. (Cubre el aparato con la mano y pregunta a Bulgákov: «QQué horario prefieres? ¿Tarde? ¿Noche?». Descubre el aparato.) ¿Stanislavsky? Aquí el camarada Stalin. (Guiña un ojo a Bulgákov.) Mire, Konstantin, no me gusta meterme en las cosas del teatro, pero tengo en mis manos una obra que... ¿Konstantin?... ¿Está 
usted ahí? (Como el teléfono funciona mal, Stalin se enfada, resopla.) Me va a oír ese ministro de Telecomunicaciones, lituano tenía que ser... Mierda de teléfono... Señorita, ¿es ahí el Teatro de Stanislavsky? Póngame con el director. Sí, con Stanislavsky, ¿es que hablo en chino? ¿Quién está al aparato? ¿Es el Teatro de Stanislavsky? Aquí el camarada Stalin. ¡No se ponga nerviosa, no cuelgue! ¿Me pone o no me pone con el director? (Silencio.) ¿Qué demonios pasa con este teléfono? (Se ha cortado. Stalin cuelga, colérico.) Lituano tenía que ser, ese imbécil. (A Bulgákov.) Y tú, ¿harás el favor de quitar de mi vista esa camisa? ¿No te he dicho mil veces lo que opino de ella?

(Silencio. Stalin necesita un tiempo para calmarse.)

Stalin.-Perdóname. Perdona que te haya hablado así. Sabes lo mucho que te respeto. Es sólo que... Estoy rodeado de incompetentes... Te prometo que mañana mismo me ocuparé de esa nueva obra tuya. Deja que le eche un vistazo. (Se sienta y abre el manuscrito.) Tu letra ha cambiado mucho durante estos años. Antes era ancha y regular. Se ha vuelto muy apretada. Hay palabras que no entiendo. Nos estamos haciendo viejos, Mijail.

(Stalin lee en silencio. Bulgákov observa sus reacciones ante el manuscrito. Algunas son positivas; otras resultan más difíciles

de interpretar. Bruscamente, Stalin se levanta para irse.)

Bulgákov.—¿Se va usted?

Stalin.- ¿No querías estar solo?

Bulgákov.-(Señalando el manuscrito.) ¿No va a decirme qué le parece?

STALIN.-Tengo que hacer.

Bulgákov.-(Señalando el manuscrito.) ¿No cree que el paso de la segunda a la tercera escena...?

STALIN.-(Interrumpiéndole.) Lo siento, Mijail, tengo mucho trabajo.

BuLGÁKov.-Excusas.

STALIN.-Tengo que cubrir el país con una gran red telefónica, desde Kaliningrado hasta Kamchatskiy. Eso lleva su tiempo.

Bulgákov.-No puede irse todavía. Tenemos que hablar de mi viaje. STALIN.—¿Viaje? ¿Qué viaje? 
BULGÁKov.-Mi solicitud de salir al extranjero... Si es que una obra como ésta no puede ser escrita en la Unión Soviética.

STALIN.-Ah, te refieres a eso...

BULGÁKov.—¿Ha decidido usted algo al respecto?

STALIN.-Pero si ya has estado en el extranjero, Mijail.

BULGÁKov.-Jamás.

Stalin.-Según la Enciclopedia Soviética, estuviste en Finlandia en 1921.

BULGÁKOV.-Esa información es errónea.

STALIN.-¿Errónea? Una información de la Enciclopedia Soviética, ¿errónea?

Bulgákov.-Nunca he estado en Finlandia. Nunca he puesto un pie fuera de la Unión Soviética, nunca...

STALIN.-(Interrumpiéndole.) ¿Dónde te gustaría ir? (Saca una mapa del mundo. Lo extiende ante Bulgákov. Lo recorre con la mano.) ¿Roma? Demasiado calor. ¿Bruselas? (Cara de desprecio.) ¿Y Londres? En Londres te las arreglarías bastante bien. Podrías hacer como Ilia Ehrenburg, que escribe para que le traduzcan. $O$ podrías aprender a escribir en inglés, como el polaco Joseph Conrad. ¿O sueñas con los museos de París? ¿Con las olas del Mediterráneo? (Stalin sostiene el mapa abierto ante Bulgákov. Silencio.) No puedo imaginarte fuera de tu patria. (Guarda el mapa.)

Bulgákov.-Si se me permitiese ser útil a mi patria... (Le muestra el manuscrito.) Si algún teatro de la Unión Soviética...

STALIN.-(Interrumpiéndole.) Escucha, ya sé lo que vamos a hacer: me resumes por escrito tu petición, convenientemente razonada, la metes en un sobre y me la envías al despacho. Veré qué se puede hacer.

BULGÁKov.-Usted no responde a mis cartas. ¿Las rompe sin leerlas? ¿Las rompe después de leerlas? ¿Las conserva? ¿Dónde? ¿Todas juntas, separadas del resto de la correspondencia, o mezcladas con otras? La carta del 7 de mayo de 1931, ¿la leyó usted? ¿Ha leído alguna de mis cartas? ¿Subraya las frases que le parecen importantes? ¿Busca en el diccionario las palabras que desconoce? ¿O es que no llegan a sus manos?, ¿por eso no las contesta? Si hubiese escrito 
mal la dirección, me las habrían devuelto. Que yo recuerde, nunca he olvidado firmarlas. Debe de ser que pasan de funcionario a funcionario y se extravían por el camino. ¿Cuántos leen mis cartas? ¿Pasan de despacho a despacho entre los ministros del Gobierno? ¿Y si son interceptadas? No puedo confiar en el correo. Mi mujer debería entregárselas en mano, pero ¿puedo fiarme de ella? No ve con buenos ojos nuestra relación. Debería llevarlas yo mismo al Kremlin. Y esperar su respuesta a las puertas del Kremlin tanto tiempo como fuese necesario. Pero no debo moverme de aquí. Usted puede telefonear en cualquier momento.

\section{(Pausa. Stalin lo lleva ante la pluma y el papel.)}

STALIN.-No te desanimes. Encontrarás las palabras justas. Zamiatin lo consiguió.

BULGÁKov.-Zamiatin lo convenció con una sola carta.

StALIN.-Encontró las palabras adecuadas. También tú lo conseguirás.

BULGÁKov.-Durante años, Zamiatin compartió conmigo el papel de diablo. Pero, con unas pocas palabras, cambió su suerte. ¿Cuál ha sido mi error?

STALIN.-Zamiatin me escribió una carta muy clara. Su deseo era claro. Sabía lo que quería. Curioso personaje, tan pequeño, tan asustado. (Lo imita.) «Fui un niño solitario. Me pasaba las horas en el sofá, sobre un libro».

Bulgákov.—¿Recibió a Zamiatin? ¿Conversó con él cara a cara?

STALIN.-En cuanto leí su carta, entendí lo que quería y lo mandé llamar. (Lo imita.) «De mi pueblo recuerdo un cochinillo atado a una estaca, unas gallinas en una nube de polvo». (Deja de imitarlo.) «Se ve que amas mucho a Rusia, Zamiatin. ¿Dónde naciste?». (Lo imita.) «En el mismo centro del mapa hay un círculo diminuto: Lebedian, en la provincia de Tambov». ¿Has estado alguna vez en Lebedian, Mijail?

Bulgákov.-Leí algo sobre ese lugar en Tolstoi. ¿O fue en Turguéniev?... Así que se entrevistó personalmente con él.

Stalin.- ¿Sabías que a Zamiatin, siendo un muchacho, un perro rabioso le mordió una pierna? Como le gustaba experimentar consigo mismo, decidió esperar a ver qué pasaba: (Lo imita.) «¿Me volveré loco?; ¿qué sentiré cuando empiece a volverme loco?». 


\section{(Stalin ríe a carcajadas.)}

Bulgákov.—¿Por eso le dejó salir de la Unión Soviética? ¿Porque le hizo reír?

STALIN.-No comprendes nada, Mijail. Nada de nada... El caso es que Zamiatin masticó trocitos de jabón y se presentó al maestro de la escuela con la boca llena de espumarajos. Convenció al maestro de que lo enviase a San Petersburgo, porque en Lebedian no tenían vacuna contra la rabia. Así es como Zamiatin llegó a San Petersburgo. Quería ir allí y así fue como lo consiguió. ¿Conocías esa historia?

Bulgákov.-Me la ha contado mil veces. Zamiatin siempre cuenta las mismas patrañas. También le contaría que, cuando llegó a San Petersburgo, sólo tenía una medalla que le habían dado en Lebedian por sus buenas notas. Y que, al estallar la Revolución, llevó su medalla a una casa de empeños, y el dinero que le dieron se lo envió a Lenin para ayudar a los bolcheviques.

STALIN.- ¿Y no fue así?

Bulgákov.-Zamiatin no fue a San Petersburgo a que lo vacunasen contra la rabia, sino a estudiar en la Universidad. Y luego se marchó a Inglaterra a trabajar. Estaba en Inglaterra cuando llegó la Revolución. Se enteró de la Revolución por los periódicos ingleses.

Stalin.-Así que no estaba en Rusia en octubre. Valiente embustero. No debí dejarle salir. No estaba en Rusia en Octubre. Cuando volvió, se lo encontró todo hecho. Es como no haberse enamorado nunca y encontrarse una mañana casado desde hace diez años. ¿Y tú, Mijail, dónde estabas tú en octubre? ¿Dónde estabas cuando se amotinó el Potemkin? ¿Y durante la rebelión de Sveaborg? Qué tiempos aquellos, Mijail. ¡Qué tiempos aquellos!

Bulgákov.-Aún no entiendo por qué le dejó salir. No puede ser un capricho, usted no hace nada por capricho. ¿Es Zamiatin mejor que yo? ¿Es ése el problema? No soy lo bastante bueno.

STAlIN._ ¿Cómo puedes decir eso? (Recita, de memoria.) «Estimado Iosif Visarionovich. Sombríos presagios se arrastran a mi alrededor como serpientes...». En tu última carta has alcanzado el punto más alto de tu obra. Te preguntarás por qué entonces no tomo de una vez una decisión. Mijail, tienes enemigos. Tantos, que me es imposible no escucharlos. A mis oídos llegan comentarios horribles sobre ti. Sin embargo, tus cartas son mejores cada día. Estoy convencido de 
que estás a punto de escribirme la carta adecuada, una carta mucho mejor que la de Zamiatin. Todo este tiempo no ha sido en vano, Mijail. Estás a punto de conseguirlo. Ahora más que nunca, no debes dejar que nada te distraiga. (Toma el manuscrito.) Un arranque muy ingenioso, siempre me sorprenden tus primeras escenas. Será una obra magnífica. Pero no olvides cuál debe ser, hoy por hoy, tu principal objetivo. (Aleja de Bulgákov el manuscrito y pone ante él la carta. Va a salir. Se vuelve. Señala el manuscrito.) Deberías guardar bien esos papeles, no vayan a caer en malas manos. Te enviaré a alguien para que te ayude a guardarlos.

(Stalin sale. Al salir, se ha cruzado con la mujer. Ésta viene de la calle. Bulgákov no la mira. Pausa.)

Bulgákova.-Hasta el último momento, pensé: «Mijail sabe que es peligroso. No me dejará ir sola». Hay otro Moscú, ¿sabes?, más allá de los muelles. Allí el río está sucio, los cuervos se posan sobre la nieve de la orilla. Estaba pensando «Mijail debería estar aquí, conmigo», cuando oí el silbido de un hombre que me sonreía con las manos en los bolsillos. Caminé detrás de él un cuarto de hora o más. Entró en una casucha y pensé: «En el último momento, Mijail aparecerá». En la casucha había una mesa llena de pasaportes sin foto y sin nombre. El hombre dijo: «¿Ha traido las fotos?». Luego me preguntó los nombres. Deberías haber estado conmigo, cuando le dije tu nombre. (Pausa.) Ni siquiera en el mercado negro. Nadie quiere vender un pasaporte a Mijail Bulgákov. Hasta los peores escupen, en cuanto menciono tu nombre.

(Bulgákov y la mujer se miran en silencio. Hasta que ella descubre el manuscrito. Se pone muy contenta.)

Bulgákova.- ¿Una novela? ¿La segunda parte de La guardia blanca? (Lo toma. Lo hojea.) ¡Una obra de teatro!

(Bulgákov le arrebata el manuscrito.)

Bulgákova.- ¿No vas a leérmela?

(No hay réplica.)

BULGÁKova.- ¿Ni siquiera vas a decirme de qué trata?

BULGÁKov.-Del diablo. Estoy escribiendo sobre el diablo.

(Bulgákov entierra el manuscrito bajo las cartas.) 
(Pausa. Las cartas han invadido el lugar. Bulgákov no lleva su vieja camisa. Las manos de Stalin están pintadas de blanco.)

STALIN.-¿Mijail Afanásievich Bulgákov?

BULGÁKOV.-Yo soy.

STALIN.-Buenos días, camarada Bulgákov.

Bulgákov.-Buenos días, Iosif Visarionovich.

STALIN.-Hemos recibido sus cartas. Las hemos leído con los camaradas. Quiere marcharse al extranjero, ¿no es eso? Está harto de nosotros.

BULGÁKOV.-UÚltimamente me he hecho mil veces la misma pregunta: ¿Puede un escritor ruso vivir fuera de su patria?

STAliN.-Yo también me hago a menudo esa pregunta. Pero hablemos de usted. ¿Dónde quiere trabajar? ¿En el Teatro de Stanislavski?

Bulgákov.-Claro que me gustaría. Pero no he recibido más que negativas.

StaLIN.-Presente una solicitud. Tengo la impresión de que esta vez la aceptarán. Tendríamos que reunirnos para charlar.

BULGÁKOV.-¡Oh, sí, Iosif Visarionovich, tenemos que conversar!

STALIN.-Habrá que encontrar un momento apropiado para ello.

(Pausa larga. Stalin escribe allí donde Bulgákov solía hacerlo; Bulgákov no escribe.)

BuLGÁKOv.-No comprendo. Estabas a punto de convocarme a un encuentro cara a cara. ¿Por qué no hemos llegado a encontrarnos? Me rompo la cabeza tratando de comprender. Tratando de comprender qué ha sucedido desde entonces.

STALIN.-No es hacia atrás, sino hacia delante donde tienes que dirigir tu mirada. ¿No ves en el futuro nada para ti?

BulgáKov.-Debí adelantarme y proponerte una fecha y una hora. Me faltó valor. ¿O fue el cansancio? ¿O la sorpresa? Llevaba tanto tiempo esperando... Me levantaba y me acostaba con ello en la cabeza. De pronto, suena el teléfono. Fue como un milagro. Mi gran 
ocasión. Ahora ya no hay nada que hacer, es demasiado tarde. Cometí un error fatal. Arrastraré mi culpa mientras viva.

STALIN.— - Arrastraré mi culpa mientras viva». ¿Por qué siempre tienes que ponerte tan trascendente? «Cometí un error fatal». Si no lo hubieses cometido, ¿el sol brillaría de otro modo?

BULGÁKov.-Si no lo hubiese cometido, ahora estaría escribiendo, en lugar de hablando solo como un poseso.

Stalin.-Me aburre tu continua queja. Te pasas el día refunfuñando.

Bulgákov.-Podrías decirme: «No escribas más, dedícate a otra cosa». A lo mejor me lo has dicho. ¿Me lo has dicho?

STALIN.-No me marees, Mijail, tengo mis propios problemas. ¿Sabes cuánto cuesta un metro de hilo telefónico?

Bulgákov.-No comprendo nada. ¿Por qué se retiene a un escritor cuyas obras no se autorizan? Si al menos levantases la prohibición sobre Los días de los Turbín...

Stalin.-Hablas como si en la Unión Soviética se hiciese mi voluntad. ¿Crees que no cuenta la opinión de los otros camaradas? Molotov, Kalinin, Yagoda...

Bulgákov.-Has hecho borrar mi nombre de todos los teatros de la Unión Soviética.

STALIN.-Qué injusto eres. Bien sabes que soy tu más fiel espectador. He visto quince veces Los días de los Turbín, ocho veces El apartamento de Zoika. Puedo recitar escenas enteras de tus obras. En particular, de aquellas que los camaradas y yo hemos tenido que prohibir. Ponme a prueba. ¿Quieres oír La isla púrpura de arriba abajo? (Recita.) «iDimitri, los obreros están ensuciando con sus botazas el mármol de la escalera!...».

BULGÁKov.-Lo peor no es que yo esté desesperado. Lo peor es que también mis obras lo están.

STALIN.-Stalin te lee. ¿Qué más quieres?

Bulgákov.-Todo lo que he escrito está en una situación desesperada.

STALIN.- ¿No sabes hablar de otra cosa que de lo mal que te va en la vida? Vives de las heridas. De chupar tus heridas. De que no se cierre la herida, de eso vives tú. En lugar de pasarte los días y las noches dándole vueltas a aquella maldita llamada, podrías hacer algo positivo. Sabes a qué me refiero. 
Bulgákov.-Eso nunca.

STALIN.- ¿Nunca cambiarás, Mijail? Tú crees que la gente no puede cambiar, ¿verdad? Ése es el tema de todas tus obras: la gente no puede cambiar. También de esa pieza que estabas escribiendo últimamente. ¿Qué es de ella? Aquella obra sobre el diablo.

Bulgákov.-Tú sabrás. Entraron unos policías y se llevaron el manuscrito. Dijeron que se lo llevaban al GPU. ¿Qué es el GPU? ¿Llamáis así ahora la censura, GPU?

Stalin.-_GPU? La primera vez que lo oigo. Preguntaré a Molotov. GPU...

Bulgákov.-Lo pusieron todo patas arriba. Traían un papel oficial: «Orden 2.287, expediente 45».

STALIN.-GPU... Preguntaré a Molotov. Pero dime: ¿Has escrito más escenas?

Bulgákov.-Ni una palabra. Es imposible escribir después de un registro, sabiendo que te vigilan.

STALIN.-Tú, tranquilo. ¿Te hemos arrestado alguna vez?

Bulgákov.-Pero ¿y mi obra? ¿Qué han hecho con ella? ¿La han quemado?

STALIN.-Eso es imposible. Los libros no arden. Y menos esa clase de libro. Una obra muy interesante en su planteamiento. Confusa, sin embargo, en su desarrollo. El arranque es magnífico: un hombre y una mujer a los que visita el diablo... Lástima que el personaje de ella esté tan poco desarrollado. Te lo he dicho muchas veces: tu punto débil es siempre el personaje femenino. ¿Y si tratases de hacerla un poco más compleja? Por ejemplo: ¿Y si fuese ella la que abre la puerta al demonio? La imagen central es formidable: el diablo paseándose por Moscú, entrando en las casas de la gente... Tienes tanto talento, Mijail, tu imaginación es tan poderosa... Pero ¿por qué todo lo que escribes tiene que ser seco y sombrío? Esas colecciones de rusos que parecen sacados de un manicomio... Como si la Revolución no los hubiese cambiado ni un poquito. Te gusta destacar las monstruosidades de nuestra gente, los peores rasgos de nuestro pueblo... ¿Por nada del mundo escribirás una obra que haga feliz a Stalin?

(Pausa. Bulgákov niega.) 
STALIN.- ¿Ni siquiera por ella lo harás?

(Señala a la mujer, que viene de la calle. Agotada. Ya no le extraña ver a Bulgákov hablando solo. Tiende una carta a Bulgákov.)

Stalin.- Reconozco que estaba equivocado respecto a ella. Pensé que se vendría abajo. Pero no, hasta ha aprendido a coser. Aunque ia qué precio? Mira sus manos. ¿Cuántas veces se hirió remendándote aquella camisa? Pobrecita. No fue educada para esto. ¿Cuántas veces te remendó aquella camisa? ¿Mil veces? ¿Un millón de veces? No quiere aceptar que el mundo ha cambiado. ¡Estamos en el siglo veinte! Pobrecita. La sombra de tu desgracia ha caído sobre ella. Yo pensaba: «Se vendrá abajo. Le pedirá de rodillas que escriba una obra para Stalin». Pobrecita. Las cosas que tiene que oír sobre ti. La gente es así, creen lo que leen en Pravda. Escupen el suelo que pisa, en cuanto menciona tu nombre. Incluso en el mercado negro, allí donde sólo van los traidores.

Bulgákov.-(A su mujer.) Te dije que no era el camino correcto. Hay que ir directamente a Stalin.

STALIN.-Pobrecita. Está a punto de estallar. «Nunca nos ayudará, Mijail. A menos que... ¿Quieres que escapemos de la miseria? Si es así, toma la pluma y da una alegría a ese cerdo».

BULGákov.—(A su mujer.) No puedo.

STALIN.- «Sabes escribir mentiras. Escribe las mentiras que Stalin quiere oír».

Bulgákov.-(A su mujer.) No.

STALIN.-《¿Ni siquiera lo intentarás?».

Bulgákov.-(A su mujer.) No sería capaz. Aunque lo intentase con todas mis fuerzas.

STALIN.— «Llámale y dile que te dicte. Que firmarás la obra que a él se le antoje, con burgueses envenenando a ancianitas y bolcheviques repartiendo naranjas a los niños».

Bulgákov.-(A su mujer.) Lo mejor que puedo hacer es escribirle una carta.

\section{(Toma papel y pluma.)}

STALIN.- «Por una vez, ¿podrás tragarte tu estúpido orgullo? ¿Serás capaz de fingir una pizca de arrepentimiento? ¿De disimular tus 
ideas? ¿Podrás escribirle algo así como: «Le aseguro, camarada, que en el futuro seré su más leal compañero de viaje»?».

BULGÁKov.-(A su mujer.) ¿Lo tomas por tonto? No me ganaré su simpatía con embustes. Debo dirigirle una carta sincera. Cuando se trata de Stalin, sólo vale una cosa: la verdad.

STALIN.- «La verdad no nos ha ayudado hasta ahora. ¿Dónde nos ha arrastrado, tanta verdad?».

Bulgákov.-(A su mujer.) Le pediré una cita. Cara a cara, le haré comprender mis razones.

STALIN.— «Nunca te recibirá. No quiere hablar contigo».

BULGÁKOV.-(A Stalin.) Ella cree que fue una alucinación. Que en realidad nunca me telefoneaste. Sin embargo, yo escuché perfectamente cómo me decías: «Camarada Bulgákov, no podemos permitirnos prescindir de usted. Vamos a encontrarnos usted y yo para hablar acerca de su futuro». ¡Lo dijiste! ¡Querías recibirme! Pero ¿qué ha pasado desde entonces? ¿Qué está pasando? Ella cree que aquella llamada fue una trampa. Que condujiste la conversación conforme a tus intereses y la interrumpiste cuando te vino bien. Que me manejaste.

STALIN.-A menudo me pregunto si esta mujer te conviene.

Bulgákov.-La convivencia con ella se está volviendo imposible. Cada día es peor.

STALIN.-Por lo menos te ha quitado aquella camisa espantosa.

BULGÁKov.-No me la ha quitado. Yo mismo tuve que tirarla por la ventana. Insoportable, se está poniendo insoportable.

STALIN.-Y todo el día mareándote con el mismo serial: «La vuelta al mundo de Zamiatin».

Bulgákov.-Telegrama de Zamiatin desde Amsterdam; postal de Zamiatin desde España...

STALIN.- ¿Y en la cama?

Bulgákov.-No sé. Desde hace tiempo... No sé qué me pasa.

STALIN.-Lo dices como si fuera tuya la culpa.

Bulgákov.-No sé. 
STALIN.—¿Ha conseguido hacerte creer que tú eres el culpable? ¿Y todavía se atreve a decir que yo te manejo? Te sientes culpable de estar conmigo en lugar de con ella, ¿no es así? Verdaderamente, esta mujer sabe cómo moverte los hilos. Ni siquiera te atreves a tocarme.

(Pausa. Bulgákov se atreve a tocar a Stalin. Silencio.)

BULGÁKOV.-Si al menos volvieras a llamarme...

STALIN.- ¿Estás intentando sobornarme, Mijail?

BULGÁKOV.-No, no.

STALIN.-Corromperme.

BuLgákov.-No.

STALIN. - Corromper a la nación. ¿Es eso lo que pretendes?

(Se aparta bruscamente de Bulgákov. Éste queda en el aire, como aquél a quien el amante se le evapora entre los brazos.

Su mujer todavía le tiende la carta.)

Bulgákova. - Carta de Zamiatin desde París.

(Pausa.)

Bulgákova.-No es para ti. La envía a mi nombre. Quiere que me vaya con él. Ya sabes cómo es Zamiatin. Siempre sabe lo que quiere, y siempre habla claro.

(Pausa. Deja la carta. Se acerca a él. Lo toca.)

Bulgákova.-Vayamos a la frontera, Mijail. Tú y yo, sin papeles, sólo con nuestra voluntad. Vamos a la frontera. Para atravesarla, sólo necesitamos estar juntos.

(Pausa.)

BULGÁKOV.—¿Irme de Rusia?

Bulgákova.-Sólo necesitamos estar juntos. Donde sea. Mijail, donde tú quieras, con tal de que estemos juntos.

(Pausa.)

Bulgákov.-¿Irme de Rusia? ¿Ahora, cuando él está tan cerca de aceptar mi punto de vista? Mi última carta le ha producido una honda impresión. 


\section{(Pausa.)}

Bulgákova.- ¿Por qué no te mata? ¿Por qué no envía a alguien a que acabe el trabajo? Habría muchos dispuestos a hacerlo. Todos esos que me escupen. Todos me escupen, en cuanto menciono tu nombre.

STALIN.-(A Bulgákov. ¿Tiene que ir a todas partes con tu nombre por delante? Seguro que podría conseguir un pasaporte para sí misma. Incluso en el Comité de Asuntos Extranjeros, siempre que no vaya cacareando tu apellido. Dile que solicite un permiso para viajar sola al extranjero. Se lo entregarán al instante.

Bulgákov.-No querrá irse sin mí. Habrá que obligarla, Iosif Visarionovich. Sácala de Rusia, lejos de nosotros, donde no pueda hacernos daño.

\section{(Bulgákov calla.)}

STALIN.-(Recita.) «iDimitri, los obreros están ensuciando con sus botazas el mármol de la escalera! ¡¿Quién ha quitado la alfombra?! ii¿Es que Marx prohibe cubrir con alfombras las escaleras?!!». (Silencio.) Ninguno de tus actores te ha entendido como yo. ¿Sabes por qué, Misha? Porque nadie te conoce como yo. Igual que nadie me conoce como me conoces tú. Por eso me siento tan a gusto aquí, contigo. En cuanto puedo, agarro el abrigo y me vengo a tu casa. Cada día aguanto menos el Kremlin. Es tan aburrido, con todos esos burócratas y políticos... Estoy rodeado de intrigantes. Molotov y los demás, si oyeras las cosas que me dicen sobre ti... No tienen sensibilidad, y sospechan de cualquiera que la tenga. No sé qué harían conmigo si se enteraran de que también yo escribo poesía. (Silencio. Stalin saca un papel.) «La mañana». (Silencio. Recita.) «La brisa huele a trigo y a tractores. / Al despertar, la tierra / saluda a los campesinos. / Alegres abren / surcos al nuevo día. / Más allá, rasgando / el velo de las nubes / cantan los aviadores: / "Patria, danos tus frutos. / Nosotros te daremos nuestro trabajo"». (Espera la reacción de Bulgákov. Silencio.) ¿Sabes lo que más respeto de ti, Misha? Que no tienes miedo a las palabras. En unos tiempos en que una sola palabra te puede costar la vida, tú siempre dices lo que 
piensas. (Espera la reacción de Bulgákov. Silencio. Rompe el papel.) Tienes razón. No he nacido para la poesía. La poesía ablanda el alma. Un luchador no puede ser poeta. ¿Sabes cuántos kilómetros de teléfono he extendido en tres meses? Tú eres el poeta y yo el luchador. (Silencio.) Pero ¿acaso no tengo derecho a soñar con una poesía para luchadores? ¿No tengo derecho a soñar con una cultura revolucionaria? Ésa es la pregunta que me desvela noche tras noche. ¿Podemos fiarlo todo a esos artistas que se llaman a sí mismos «de izquierdas»? Tienen el carnet del partido, pero ¿tienen talento? Saben cuándo ponerse el gorro rojo y cuándo quitárselo; cuándo cantar loas al zar y cuándo a la hoz y al martillo. Pero ¿pueden hacer un arte digno de la Revolución? (Silencio.) Necesitamos hombres como tú, Misha. Artistas de verdad. Lástima que os cueste tanto entender lo que el pueblo necesita de vosotros. Fíjate en el pobre Maiakowski. Hizo bien en pegarse un tiro. Ya no era aquel joven Maiakowski que a cada paso abría un sendero en el bosque. El viejo Maiakowski salió del bosque a una carretera asfaltada, se dedicó a poner en verso mis decretos. ¿Creía que era eso lo que yo esperaba de él, que pusiese en verso mis decretos? Hizo bien pegándose un tiro. (Silencio.) ¿Cuál es la causa del silencio del arte verdadero? ¿La miseria? No. Los artistas rusos estáis acostumbrados a pasar hambre. La razón de vuestro silencio no es la falta de pan, sino una mucho más profunda. El arte no pueden hacerlo leales funcionarios, sino herejes peligrosos como tú. Si un escritor intenta ser leal, si intenta ser útil, hará una literatura que se lee hoy y con la que mañana se envuelve la pastilla de jabón. (Silencio.) ¿Por qué a los verdaderos artistas os costará tanto entender lo que el pueblo necesita de vosotros? El corazón del pueblo es tan caprichoso... Es mucho más fácil defender al pueblo de sus enemigos que defenderlo de los que lo aman. ¿Sabes que incluso la obra de Gorki El obrero Solovotekov, incluso esa inocentísima obra, hemos tenido que retirarla del repertorio? Como lo estás oyendo, Misha, El obrero Solovotekov, ¿crees que no me duele? Mírame a los ojos, Misha, mírame cuando te hablo. Es mucho más fácil defender al pueblo de sus enemigos que defenderlo de sí mismo. Qué más quisiéramos los camaradas y yo que la Unión Soviética estuviese llena de verdaderos artistas. ¿Acaso al arte ruso sólo le queda un futuro: su pasado? Dímelo tú, Misha. ¿Por qué no me miras? ¿Es que te doy miedo, por eso bajas la mirada? ¿Alguna vez te he puesto la mano encima? Estoy cambiando, Misha, tú me has hecho cambiar. Ya no soy aquel bruto insensible. Ayer noche, leyendo tu última carta, se me saltaban 
las lágrimas. No me crees, ¿eh? Tú piensas que la gente no puede cambiar. Pero la Revolución está cambiando a la gente. ¿Sabes cuántos kilómetros de teléfono vamos a extender en el próximo quinquenio? ¿Y en el siguiente? Muy pronto te voy a hacer llamar y vamos a conversar acerca de ello. Me gustaría tanto tenerte allí, en el Kremlin, tener allí un verdadero amigo. No puedo probar bocado sin miedo a que me envenenen. No puedo abrir la boca sin miedo a que me hayan envenenado el aire. Muy pronto podrás venir a verme. En cuanto estés preparado. Un poco de paciencia, Misha. No dejo de pensar en ti. Me preocupa tu aspecto. Te conviene salir de casa. Mezclarte con la gente. Si sigues apartándote del pueblo, enloquecerás. Paciencia, Misha, muy pronto la gente volverá a quererte. En cuanto estén preparados. No habrá verdadero arte mientras el pueblo sea como un niño cuya inocencia hay que salvaguardar. Entretanto, los camaradas y yo llenaremos de teléfonos la Unión Soviética. Haremos que cada hogar, desde Kalinigrado hasta Kamchatkiy, tenga su propio teléfono para hablar directamente con Stalin. Te juro, Misha, que lo conseguiremos. Cueste lo que cueste.

(La mujer ha entrado con sus maletas, vestida para salir de viaje. Ha ido al lugar donde Bulgákov escribía. Ha recogido un manuscrito de Bulgákov para llevárselo consigo. Ha mirado a Bulgákov por última vez. Se ha ido sin dirigirle un gesto de despedida.) 